\title{
DE POR QUÉ JUAN RAMÓN JIMÉNEZ RENUNCIÓ A SER NOVELISTA: EL POETA Y SU TEORÍA DE LA NOVELA
}

\author{
M. ${ }^{a}$ ÁNGeles SANZ MANZANO \\ Universidad de Alcalá de Henares
}

Inherente al oficio de creador es la inquietud por explorar el infinito universo de las formas. En algunos poetas, en los más grandes «hacedores» del lenguaje, esta inquietud actúa como estímulo y fuerza rectora de toda su trayectoria. No conformarse con la forma ya doblegada y emprender sin descanso la búsqueda de la que aún está por conquistar o, incluso, por inventar se convierte, a un tiempo, en imperativo y reto. A este grupo de poetas pertenece Juan Ramón Jiménez.

En su verso y en su prosa, los dos cauces por los que discurre su «Obra» ${ }^{1}$, el poeta de Moguer hace gala del mismo talante indagador. Como poeta en verso, dedicó buena parte de su andadura a explorar todas las posibilidades que le ofrecía la tradición del verso regular. Así, reunió en sus poemarios: romances ${ }^{2}$, canciones ${ }^{3}$, sonetos ${ }^{4}$, versos alejandrinos ${ }^{5}$, entre otras muchas estrofas. No satisfecho con ello, también se aventuró a transitar por los caminos, entonces todavía ignotos, del «verso libre» ${ }^{6}$.

\footnotetext{
1 De este modo, con letra mayúscula, se refería Juan Ramón a la totalidad de su producción literaria.

2 Juan Ramón inició su trayectoria poética sirviéndose de esta forma métrica en libros como Arias Tristes (1903) y mantuvo su gusto por ella hasta el final de su vida, tal y como lo demuestra el libro Romances de Coral Gables (1948). Para conocer el significado que el poeta otorgó al romance en su poesía y en la historia de la poesía española ver «El romance, río de la lengua española» en El trabajo gustoso, ed. de Francisco Garfias, México, Aguilar, 1961, pp. 143-187.

3 Canción fue el título elegido por el poeta para publicar en 1936 el primero y único de los siete volúmentes que proyectó para la «edición definitiva» de su obra.

4 Sonetos espirituales, libro escrito entre 1914 y 1915 y publicado en 1917 , está íntegramente compuesto por poemas escritos en esta forma métrica.

5 Aparecen en sus Elejías, publicadas por separado en tres secciones: «Elejías puras» (1908), «Elejías intermedias» (1909) y «Elejías lamentables» (1910).

6 Fue en 1916 con su Diario de un poeta reciencasado, libro que en opinión del propio poeta (cfr. Conversaciones con Juan Ramón Jiménez, ed. de Ricardo Gullón,
}

Rlit, LXV, 130 (2003), 471-500 
Sabedor de que la prosa le ofrecía no menos variedad formal que el verso $^{7}$, desplegó una frenética actividad como poeta y crítico en prosa. De su pluma salieron multitud de poemas en prosa, «caricaturas líricas», aforismos, prólogos, conferencias, artículos, reseñas e, incluso, hizo su incursión en el género narrativo al escribir «cuentos largos» ${ }^{8}$. Hubiera sido de esperar, que su imparable proceso de experimentación formal le condujese a la novela. Y sin embargo, Juan Ramón no publicó ninguna novela ¿Significa esto que nunca sintió la tentación de escribir alguna?, ¿cuál fue, con exactitud, la relación que mantuvo el poeta con el género de la novela? En los innumerables papeles que se conservan en sus archivos y en los juicios que fue dejando el poeta de manera dispersa sobre el género se pueden encontrar las claves que permiten dar respuesta a estas preguntas.

\section{1. ÍNDICE DE PROYECTOS NOVELÍSTICOS}

La primera sorpresa surge al constatar que Juan Ramón, lejos de manifestar indiferencia o desinterés por la novela, concibió a lo largo de su vida un gran número de proyectos "narrativos. De algunos tan sólo dejó noticia de su título, de otros ofreció abundantes detalles acerca de su argumento y características.

El primer proyecto del que Juan Ramón dio testimonio llevaba por título Desnudos o Verde y alegre. Bajo uno de estos dos epígrafes, pensaba

Madrid, Taurus, 1958, p. 93) y de otros estudiosos (cfr. Carlos Bousoño, Teoría de la expresión poética, Madrid, Editorial Gredos, 1962, p. 553 y Fernando GómEZ REDONDO, «Versolibrismo y regularidad métrica: La «forma libre» de Juan Ramón Jiménez», Signa, 10 (2002), pp. 251-268; p. 254) introduce el versolibrismo en la lírica española contemporánea.

7 Asegura el poeta: «Siempre he creído en la diversidad de la prosa, como en la del verso» (Crítica paralela, ed. de Arturo del Villar, Madrid, Narcea, 1975, pp. 172-173). De nuevo, en un aforismo reitera: «Hay tantas clases de prosa (infinitas) como de verso» (Ideolojía (1897-1957) Metamórfosis, IV, ed. de Antonio Sánchez Romeralo, Barcelona, Anthropos, 1990, n. ${ }^{\circ}$ de aforismo 2827, p. 458).

${ }^{8}$ Con este título, el poeta proyectó un libro de cuentos brevísimos que finalmente dejó inédito e inconcluso. En el prólogo de la obra, entona Juan Ramón este elogio a la brevedad: «¡Cuentos largos! ¡tan largos! ¡De una pájina! ¡Ay, el día en que los hombres sepamos todos agrandar una chispa hasta el sol que un hombre les dé concentrado en una chispa; el día en que nos demos cuenta que nada tiene tamaño, y que, por tanto, basta lo suficiente; el día en que comprendamos que nada vale por sus dimensiones (...); y que un libro puede reducirse a la mano de una hormiga porque puede amplificarlo la idea y hacerlo el universo!» (Historias y cuentos, ed. de Arturo del Villar, Barcelona, Seix Barral, 1994). Además de esta edición póstuma, Juan Casamayor Vizcaíno ha ampliado la recopilación de textos en Cuentos de antología, Madrid, Libros Clan, 1999. Por su parte, Juan Paredes Núñez realizó un estudio del cuento juanramoniano en «Los «cuentos» de Juan Ramón Jiménez», Cuadernos Hispanoamericanos, 376-378 (octubrediciembre de 1981), pp. 777-784. 
el poeta escribir una «novela» «en pájinas breves» ${ }^{9}$ destinada a narrar su noviazgo y boda con Zenobia Camprubí Aymar, la que sería su inseparable compañera durante más de cuarenta años. Según se desprende del «esquema», el libro habría de iniciarse con el momento en que Juan Ramón conoció a Zenobia en 1913 y de inmediato se sintió atraído por ella. Las partes siguientes se corresponden con el relato de su «difícil» noviazgo, de su viaje a Nueva York en 1916 para contraer matrimonio y, por último, de su recorrido por varias ciudades americanas durante su viaje de novios («Boston», «Washington», «Filadelfia»). He aquí la síntesis dejada por el poeta:

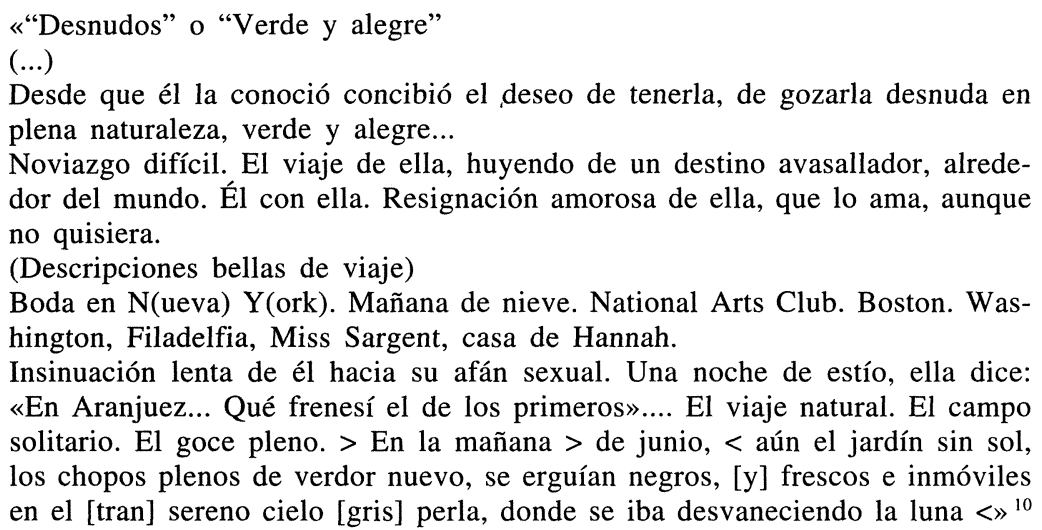

En los diseños de portada que dejó esbozados Juan Ramón para el libro figura el año 1918 como fecha del inicio de su escritura ${ }^{11}$. De este dato se infiere, que el poeta comenzó su creación por la misma época en que escribió su Diario de un poeta recién casado, publicado en 1917, que reúne tanto poemas como prosas poéticas. Ambos libros están estrechamente relacionados al compartir un mismo núcleo argumental: la peripecia vivida por el poeta durante su travesía por el mar y su estancia en Norteamérica. Obsérvese que, a diferencia de Diario de un poeta recién casado, en Desnudos, Juan Ramón elige la tercera persona del singular para contar su historia, convirtiéndose a sí mismo y a Zenobia en los personajes princi-

\footnotetext{
${ }^{9}$ En esta cita, como en todas las que se reproduzcan las palabras del poeta, se respetará su peculiar ortografía.

${ }^{10}$ Estas notas fueron publicadas por primera vez por Carmen Jiménez en su artículo «Sobre un proyecto narrativo de Juan Ramón», Culturas (suplemento cultural de Diario 16), 6 de septiembre de 1987, p. III.

11 Estos manuscritos se conservan hoy en el Archivo Histórico Nacional de Madrid (signatura 93/1 a 4). En el margen izquierdo de uno de estos bocetos (93/2), Juan Ramón indica que la portada de Desnudos había de ser idéntica a la de Eternidades, libro publicado el 1 de agosto de 1918 en la madrileña Tipografía de A. de Ángel Alcoy.
} 
pales de esta trama amorosa extraída, detalle a detalle, de su propia vida. En los apuntes del proyecto, Juan Ramón deja clara su intención de no publicar esta novela:

$$
\begin{aligned}
& \text { (Y guardarlo, en manuscrito) } \\
& \text { (...) (No publicarla. Sólo por gusto) }{ }^{12}
\end{aligned}
$$

El poeta confiesa escribir este libro sólo «por gusto», a buen seguro, por el placer de revivir y dejar constancia del que, sin duda, consideraba el episodio más trascendental de su vida: su encuentro y enlace definitivo con Zenobia. Posiblemente, porque no pensaba dar a conocer esta obra, el poeta se permitió ciertos desahogos íntimos como la detallada descripción del «deseo» que sintió por Zenobia nada más conocerla.

A pesar de tener definido con tanta claridad el plan de la novela, Juan Ramón no llegaría nunca a éscribirla. No se conserva en sus archivos ningún material más adscrito a los títulos Desnudos o Verde y alegre. Cabe sospechar que este proyecto de novela «breve» sobre su historia de amor con Zenobia pudo ser absorbido por el proyecto mayor, Monumento de amor. Esta obra, concebida por el poeta como una extensa «ofrenda lírica» a Zenobia, habría de albergar materiales muy heterogéneos: versos dedicados a su mujer, la correspondencia que ambos se cruzaron durante su noviazgo, poemas en prosa ${ }^{13}$. Todo apunta a que Juan Ramón optó finalmente por reconstruir su historia de amor de este último modo, renunciando a su proyecto novelesco.

Fue ésta la primera tentativa y el primer abandono del incipiente Juan Ramón novelista. Habrá que esperar hasta el año 1930 para encontrar nuevas noticias de sus escarceos con el género. En el transcurso de una conversación mantenida el 18 de mayo con su amigo y confidente Juan Guerrero Ruiz, el poeta le hace partícipe de su intención de «dar seis novelas intelectuales de tamaño grande que tiene completamente pensadas y mucho ya escrito» ${ }^{14}$. Además, Juan Ramón confía a su amigo valiosa información sobre el contenido de cuatro de ellas. La primera de estas novelas en ciernes lleva por título Hijo y obra y el poeta dice haberse inspirado para su argumento en la muerte del poeta austriaco Hofmannhsthal, acaecida el mismo día en que se suicidó su hijo. De este episodio doblemente trágico, llamó poderosamente la atención de Juan Ramón el hecho de que la muerte del hijo tuviera lugar en el preciso momento en que el padre

\footnotetext{
${ }^{12}$ Cito por «Sobre un proyecto narrativo de Juan Ramón», art. cit., p, III.

13 Aunque todavía está pendiente la reconstrucción completa de este libro que, como tantos otros, quedó inédito a la muerte de Juan Ramón, se pueden encontrar algunos de los textos que habían de constituirlo en Poemas y cartas de amor, ed. de R. Gullón, Santander, La isla de los ratones, 1986.

${ }^{14}$ Juan Ramón de viva voz, I, ed. de Manuel Ruiz Funes-Fernández, Valencia, PreTextos, 1998, p. 61.
} 
llegó al final de su trayectoria vital y también creativa, ya que poco antes de morir, Hofmannhsthal se había instalado en un «nihilismo» creativo parecido al que habían experimentado Mallarmé e, incluso, el mismo Juan Ramón, debido a un «exceso de producción» ${ }^{15}$. La coincidencia entre «muerte del Hijo-muerte de la Obra» despertó en el de Moguer la inquietud por reflexionar, a través de esta «novela intelectual», acerca del paralelismo «Obra-Hijo» ${ }^{16}$.

La segunda de sus novelas en preparación por aquel año de 1930 había de versar sobre una temática muy distinta: «el estudio de un carácter de muchacha moderna norteamericana» ${ }^{17}$. Para componer el retrato de la protagonista, Juan Ramón declara haber tomado como «modelo» a Inés Camprubí, sobrina de Zenobia. El poeta tuvo ocasión de conocer y observar de cerca a la joven durante el tiempo en que estuvo residiendo en su domicilio madrileño ${ }^{18}$. Mostrando una notable' capacidad inventiva, Juan Ramón ideó la siguiente trama:

${ }^{15}$ Así lo afirma el poeta en ibídem, p. 62.

16 Algunos aforismos escritos por el poeta en fechas próximas a este proyecto novelístico forman parte de esta misma reflexión. Sirvan de ejemplo los siguientes: «Nuestra poesía es como un hijo nuestro. Primero, nosotros tenemos que cuidarla, que darle cuanto tenemos. Después ella o nos da cuanto tiene o nos impone su desarrollo y su libertad» (Ideolojía, ob. cit., $\mathrm{n}^{\circ}$ de aforismo 3411, p. 584).

«La obra que no existe aún no importa tanto, pero la que existe, el hijo vivo, debe cuidarse y depurarse infinitamente para que no se avergüence de sí misma ni de nosotros» (Ideolojía, II, ed. de Emilio Ríos, Moguer, Ediciones de la Fundación Juan Ramón Jiménez, 1998, n. $^{\circ}$ de aforismo 4202, p. 19)

"¿Cómo no he tener este interés único y absorbente por mi obra, si le estoy dando mi carne?» (ibídem, n. ${ }^{\circ}$ de aforismo 4208, p. 19).

17 Juan Ramón de viva voz, I, ob. cit., p. 62.

${ }^{18}$ En su libro La ardilla y la rosa (Juan Ramón en mi memoria) (Madrid, Libros de Fausto, 1981, pp. 23-24), la escritora Ernestina Champourcin recuerda la peculiar relación que entablaron tío y sobrina. Inés Camprubí sentía por Juan Ramón una grandísima admiración; por su parte, la joven inspiraba en el poeta simpatía y, sobre todo, una enorme curiosidad. De este modo, relata E. Champourcin algunos episodios de los que fue testigo y que tienen como protagonistas al poeta y la joven americana: «(...) y empezamos a hacer excursiones, unas chistosas excursiones semiartísticas: íbamos a la Moncloa, al Pardo, y allí unas escribíamos, otras pintaban o dibujaban, y comíamos muy frugalmente, emparedados y de postre cerezas, fruta favorita de Inés porque la comía «el tío Juan Ramón», del que se iba enamorando platónicamente. Un detalle curioso, fruto de las costumbres de aquellos tiempos y que divierte en comparación con los actuales, es la discusión entre tío y sobrina porque Inés pidió enseguida la llave del portal «por si le apetecía salir a dar un paseo por la Castellana de noche», y Juan Ramón naturalmente se negaba a dársela. (...) Juan Ramón asistía a las reuniones, hablaba con todos nosotros y, y se fijaba mucho en los colores de los vestidos de las chicas, en sus peinados, etcétera. Era curioso verlo entre tanta gente joven charlando y haciendo divertidas observaciones. Por ejemplo, comentó con cierta ironía que un lunar de Marisa Pinazo, que tanta gracia le daba a su cara, cambiaba de lugar según los días». 
Esta muchacha se encuentra a un viejo pobre que anda de un modo muy lamentable, el cual es Dios que a consecuencia de un trastorno geológico ha venido a la tierra, yendo un tanto a la deriva. Ella lo acoge humanamente y le ayuda a salir delante de la situación en que se encuentra ${ }^{19}$.

Otras dos de las novelas en las que declara estar inmerso en ese mismo año eran, según su propia definición, «de tipo amoroso, pero intelectual» ${ }^{20}$. La primera de ellas se centraría en «un carácter de mujer que ya estuvo esbozando el año pasado en Lourdes» ${ }^{21}$. De la segunda, tan sólo le anticipa a su amigo Juan Guerrero que se «servirá» de ella «para hacer crítica literaria sobre un tema de fondo» ${ }^{22}$.

Entre los papeles del poeta, Ignacio Prat rescató abundante información de la novela que Juan Ramón asegura haber esbozado durante su estancia en Lourdes ${ }^{23}$. La obra había de llevar por título La Cabro. Si enigmática y extraña es su titulación, no menos inquietante es el argumento que el poeta ideó para ella. La voz narrativa corresponde al protagonista que escribe en primera persona. Según dejó dispuesto el poeta, la obra debía iniciarse con la recepción de la carta que le envía una enigmática mujer. En la misiva le requiere de la siguiente manera: «Venga a verme a Lourdes» ${ }^{24}$. El protagonista aclara que esta carta es la última de una larga serie, en la que se le fue desvelando un temperamento femenino atormentado y vehemente. Pese a todo, decide acudir a la llamada. Ambos se dan cita en un convento donde visitan a la Madre Leticia. En presencia de la monja, la mujer sufre un súbito ataque de sensualidad al que sucede otro de culpa: se siente «corrompida» frente a la pureza de la religiosa. Presa de un impulso irracional, la mujer «salta» por la ventana emulando al animal del que, desde este instante, toma el nombre «La Cabro» —que así será como la llame Juan Ramón en lo sucesivo-, produciendo en el protagonista un intenso «asco». Con el fin de vencer este rechazo y hacerse merecedora del amor de su «Amigo», la mujer emprende el camino hacia la purificación. En una larga sucesión de cartas y telegramas, «La Cabro» va informándole de su lucha por vencer la «ninfomanía» que le hace tan repulsiva a sus

19 Juan Ramón de viva voz, I, ob. cit., p. 62.

20 Ibídem, p. 62.

${ }^{21}$ Ibidem, p. 62.

${ }^{22}$ Ibídem, p. 62.

${ }^{23}$ El contenido de este proyecto fue dado a conocer por Ignacio PRAT en « $\mathrm{La} \mathrm{Ca}$ bro: una novela inédita de Juan Ramón Jiménez» en Estudios de poesía contemporánea, Madrid, Taurus, 1982, pp. 57-58.

${ }^{24}$ I. Prat recuerda la especial vinculación que tuvo Juan Ramón con la ciudad francesa, en la que estuvo en tres ocasiones: durante su período de convalecencia en el Sanatorio de Castel d'Andorte, en un viaje de placer que realizó años después y, por último, en 1930 estando ya casado con Zenobia (ibídem, p. 57). El mismo estudioso reconstruyó con toda minuciosidad la primera estancia del poeta en Lourdes en su libro El muchacho despatriado: Juan Ramón Jiménez en Francia (1901), Madrid, Taurus, 1986. 
ojos. Consigue, por fin, dar el «salto» a la «santidad católica» entregándose a la oración y siguiendo los consejos de un padre espiritual. Redimida ya su culpa, «La Cabro» viaja a Madrid con el propósito de encontrarse con su «Amigo» e iniciar una relación amorosa de tipo espiritual. Sin embargo, comprueba que la sensación de «asco» hacia ella sigue vigente en él. Entre ambos no se produce ningún acercamiento; antes al contrario, el protagonista sólo siente hacia «La Cabro» un gran «despego». La mujer se sume en la más completa desesperación: no sólo no ha logrado conquistar el corazón de su «Amigo», sino que además, al renunciar a su sexualidad, ha perdido a su marido y a su amante. Sin razones para vivir, la muerte se le presenta como la única huida posible. En pos de ella, da su último «salto» arrojándose al lago Leman. Hasta este último acto de «La Cabro» despierta en el protagonista «antipatía» además del consabido «asco». Sin embargo, cuando contemplá el rostro de la mujer muerta bajo el agua, ambos sentimientos desaparecen para ceder su lugar a los que «La Cabro» siempre quiso suscitar en él. Con estas palabras del protagonista, quería el poeta poner fin a la novela:

Pero bajo el agua su cara formó el otro aire, el embelesador, el ideal. El lívido. Pero ya era tarde ${ }^{25}$.

El tema de La Cabro tiene su origen en una de las luchas internas que más atormentaron al poeta en su juventud: su ansia de sensualidad y su anhelo, no menos intenso, de alcanzar la pureza y la perfección espiritual. La misma pugna libró el poeta en sus poemarios de entonces entre lo que para él constituían sus dos anhelos irreconciliables. Basta para demostrarlo mencionar Laberinto, libro publicado en 1913, y Libros de amor, obra que el poeta dejó inédita a su muerte ${ }^{26}$. Así pues, La Cabro representa el intento de Juan Ramón por trasladar el enfrentamiento «deseo carnal-deseo de pureza» al espacio textual de la novela. Una vez más, el proyecto quedó pendiente de desarrollo.

De nuevo, por mediación de Juan Guerrero, se sabe que en 1931, el poeta seguía firme en su propósito de escribir más novelas. Según declaró a su amigo el 28 de abril de ese año, continuaba trabajando en su libro Hijo y obra, a la vez que en otros dos nuevos libros: La muchacha y Cristo Padre $^{27}$. Aunque no facilitó a su confidente más detalles sobre su argu-

${ }^{25}$ Cito por I. PRAT, «La Cabro: una novela inédita de Juan Ramón Jiménez», art. cit., p. 57.

${ }_{26}$ Juan Ramón trabajó en este libro durante los años 1911 y 1912. En esta última fecha, la obra apareció anunciada por primera vez en Melancolía. En su edición Libros inéditos de poesía (Madrid, Aguilar, 1964, pp. 395-467), Francisco Garfias publicó gran parte del contenido del libro, dividido por el poeta en tres secciones: «1. Pasión primera, 2. Lo feo y 3. Memoria del corazón».

27 Juan Ramón de viva voz, I, ob. cit., p. 234. 
mento, el poeta afirma llevar dedicado a la escritura de estas tres novelas desde hacía «tres años», por lo que, concluye:

(...) todas están bastante escritas y sólo falta terminarlas ${ }^{28}$.

Tanto fue posponiendo Juan Ramón la fecha de terminación que, en el año 1936, el estallido de la Guerra Civil le sorprendió con todos sus proyectos de novelas sin acabar. Durante su definitivo exilio en América, el poeta retoma los borradores de dos de las novelas ya citadas - La Cabro e Hijo y obra - al tiempo que, sin interrupción, continúan sucediéndose en su mente nuevos títulos. Al fin, comprendió que el número de ideas anotadas para escribir futuras novelas se le hacía ya inabarcable y que jamás encontraría el tiempo y la energía necesarios para dar a todas cumplido desarrollo. Sin embargo, no quería resignarse a que todos estos proyectos de libros quedasen relegados al olvido entre sus miles de papeles, por lo que resuelve dar noticia de ellos en una obra recopilatoria titulada Crímenes naturales. Junto a este epígrafe, figura la nota:

boceto de novelas que yo hubiera querido escribir ${ }^{29}$.

A continuación, Juan Ramón apunta la siguiente relación de títulos: $S u$ único día, Humilde cuñado, El equivocado, La niña de las trenzas grises, En lengua extraña, El derecho, El Médico, La Momia y Una justificación ${ }^{30}$. En la actualidad, se está en disposición de ampliar este breve listado con la incorporación de muchos otros títulos. Arturo del Villar ofreció un total de veinticuatro «bocetos» de novelas correspondientes al libro Crímenes naturales en su edición Historias y cuentos $^{31}$. La labor de rastreo realizada por Javier Blasco y Teresa Gómez Trueba en los papeles manuscritos del poeta ha hecho posible el hallazgo de otros cuatro nuevos títulos de posibles novelas: La novela sin dictar, Resinas, El hombre perdiz y La niña ideal $^{32}$. Aún más recientemente, John C. Wilcox, ha dado noticia de nue-

En el Archivo Histórico de Madrid (signaturas $86 / 1$ a 6) se conservan varios manuscritos sobre un proyecto de título similar a Cristo Padre pero de intención y carácter nada novelescos. Se trata de Cristo, hombre. En las «Notas para el prólogo», expone el poeta el fin que persigue con el libro: «(...) hay que borrar la «leyenda de Cristo» y escribir la «historia de Cristo», como la historia de Buda, de Confucio, de Sócrates, de Platón. Entonces ¡qué a gusto seremos cristianos!» (86/2). También dejó indicaciones sobre la forma en que debía ser escrito: «(Libro de forma poemática, pero de fondo filosófico: claro, optimismo, bellísimo, verdadero, puro» (86/1).

${ }^{28}$ Ibídem, p. 234.

${ }^{29}$ Historias y cuentos, ed. cit., p. 50.

30 Ibídem, p. 51.

${ }_{31}^{31}$ Ibídem, pp. 214-253.

${ }^{32}$ Cfr. Juan Ramón Jiménez: La prosa de un poeta, Valladolid, Grammalea, 1994, p. 136. 
vos títulos y ha presentado su propuesta de reconstrucción y edición completa de Crímenes naturales ${ }^{33}$.

Pero no se agotó aquí la capacidad de fabulación del poeta. Todavía en 1953, ya en sus últimos años, su poderosa mente creadora seguía alumbrando nuevas «ideas» para posibles novelas. En una conversación mantenida con Ricardo Gullón el 17 de diciembre de ese mismo año en Puerto Rico, el poeta declara:

Entre tantas ideas de novela como se me ocurren hay una tentadora: poner los mitos del revés; el de Caín y Abel, por ejemplo, resultaría que el bueno mataría al peor, al preferido de mamá ${ }^{34}$.

A juzgar por las varias series de aforismos que dedicó a reflexionar sobre Narciso ${ }^{35}$, es posible que también fuera éste otro de los mitos que proyectaba «poner al revés» en una de novela.

\section{RAZONES DE UN REITERADO ABANDONO}

Tras reunir este extenso listado de proyectos de novelas, parece sobradamente probado que no fue la falta de inventiva lo que impidió a Juan Ramón convertirse en un novelista. Por si alguien albergase alguna duda respecto a su capacidad para urdir historias, dejó escrito el poeta:

Me dice: Usted podría escribir «fácilmente», con sus cualidades, unas novelas estupendas, un teatro magnífico.

¡Claro! Y por eso no los escribo ${ }^{36}$.

${ }^{33}$ El citado estudioso cree posible reunir hasta un total de cuarenta prosas. Para conocer detalladamente su plan de edición ver «Crímenes naturales: Las prosas tardías de Juan Ramón Jiménez» en Actas del Congreso Internacional Juan Ramón Jiménez prosista, Moguer, Ediciones de la Fundación Juan Ramón Jiménez, 2000, pp. 261-293. La edición en la que trabaja el profesor J. C. Wilcox verá la luz dentro del proyecto de edición completa de la prosa juanramoniana de la Editorial Espasa-Calpe, dirigido por los profesores J. Blasco Pascual y T. Gómez Trueba.

${ }^{34}$ Conversaciones con Juan Ramón Jiménez, Madrid, Taurus, 1958, p. 121.

${ }^{35}$ La primera serie de aforismos fue escrita antes de 1936 (ver Ideolojía, ob. cit., aforismos $\mathrm{n}^{\text {os }} 2981-2987$, pp. 484-485) y la segunda ya en el exilio, entre 1936 y 1949 (ver íbidem, aforismos n.os 3560-3563, pp. 616-617).

De analizar la particular interpretación que Juan Ramón hace del mito de Narciso se han ocupado Isabel de Armas en su artículo «El narcisismo «óptimo» de Juan Ramón Jiménez», Cuadernos Hispanoamericanos, 376-378 (octubre-diciembre de 1981), pp. 439445; Josefa GUERRERo HORTIGÓN en «El mito de Narciso en Juan Ramón Jiménez», Cuadernos Hispanoamericanos, 376-378 (octubre-diciembre de 1981), pp. 413-438 y M. ${ }^{\text {a }}$ Luisa AMIGo FERNÁNDEZ DE ARRÓYABE en «El mito de Narciso, arquetipo ontogenético del mundo del poeta en Juan Ramón Jiménez», Letras de Deusto, 25 (enero-abril de 1983), p. 14.

${ }^{36}$ Ideolojía II, ob. cit., n. ${ }^{\circ}$ de aforismo 4190, p. 17. 
Podría deducirse, por tanto, que fue la carencia de tiempo para desarrollar el elevado número de proyectos que se le habían ido acumulando lo que obligó al poeta a desistir de su propósito de escribir novelas ${ }^{37}$. El «creador sin escape», el vencido por el ímpetu de su propia afluencia creativa: así quedaría justificado el abandono de todos sus proyectos. Sin embargo, esta razón, en apariencia tan convincente, no acaba de explicar del todo la cuestión de por qué el poeta nunca llegó a desarrollar, concluir y a publicar ni una sola de sus novelas proyectadas. Piénsese que a la misma falta de tiempo y todavía a una mayor acumulación de proyectos tuvo que hacer frente Juan Ramón como poeta en verso y prosa. De su pluma salieron también un sinfín de títulos, ideas, índices y «bocetos» para futuras obras. Y sin embargo, aunque es cierto que muchas quedaron sin terminar, otras tantas llegaron a la imprenta y aparecieron publicadas en vida del poeta ${ }^{38}$. De esta situación tan dispar se infiere fácilmente que Juan Ramón dedicó mayor atención a su faceta de poeta que a la de novelista. Se afanó por legar una extensa obra poética, mientras que decidió renunciar a ser conocido como novelista. Fue la suya una renuncia premeditada

Respecto a la relación que mantuvo Juan Ramón con el teatro, el poeta confiesa no haber intentado nunca escribir una obra dramática (La corriente infinita, ed. de F. Garfias, Madrid, Aguilar, 1961, p. 248). En cambio, sí dejó constancia en unas notas suyas conservadas en el Archivo Histórico Nacional de Madrid (signaturas 271/1 a 3) de su intención de dirigir una colección de libros, titulada Teatro realista universal, que daría cabida a una selección de «clásicos de todos los países». Abarcaría obras procedentes de culturas tan dispares como la griega, la china, la japonesa o la árabe. Entre los autores «modernos» que pensaba editar figuran los nombres de: «Yeats, Maeterlinck, Hofmanthal (sic), Visen, D' Annunzio, Verlaine, Moreas y Samain» (271/3). Para ello, preveía contar con la colaboración de muchos de los escritores de su época, a los que asignaría las labores de traducción. En la nómina que figura en sus papeles se encuentran los nombres de: «Azorín, Unamuno, Baroja, Ortega, Ayala, A. Machado, Gabriel Miró, Moreno Villa, Onís, Alfonso Reyes, Corpus Barga» (271/2). El poeta parecía tener muy claro el modo en que debía llevarse a cabo la edición: primero se publicarían tomos pequeños, «de una sola obra»; al frente de cada todo iría un folleto explicativo. Cuando se hubiera llegado a un número estimable de libros, se reunirían en tomos de tres obras (271/3). Juan Ramón quería inaugurar la colección con La tempestad de Shakespeare.

${ }^{37}$ Precisamente, éste es el argumento que sostiene A. del Villar: «Perdimos, pues, un novelista en Juan Ramón Jiménez, que contaba con argumentos y bocetos para desarrollarlos cuando hubiera encontrado tiempo. Y su falta debió de ser probablemente la causa de que no adelantase su propósito. Piénsese en su labor creadora y correctora, en las traducciones, colaboraciones en revistas y diarios, correspondencia, entrevistas y demás obligaciones cotidianas para entender que no consiguiera desarrollar temas redactados en parte» («Prólogo» a Historias y cuentos, ed. cit., p. 51).

${ }^{38}$ Para hacerse una idea aproximada de la magnitud de la «Obra» juanramoniana y las más diversas formas de publicación a que recurrió el poeta (libros, revistas, periódicos, cuadernos, hojas sueltas) resulta imprescindible consultar la exhaustiva obra de Antonio CAMPOAMOR, Bibliografía de Juan Ramón Jiménez, Moguer, Ediciones de la Fundación Juan Ramón Jiménez, 1999, 2. ${ }^{a}$ ed., pp. 19-210. 
y consciente que hizo saber por primera vez a su amigo Juan Guerrero el 28 de abril de 1931:

(...) pero yo no quiero ser novelista, aparecer como novelista, y entonces lo que pienso hacer es darlas como traducciones, inventando un nombre que responda a apellidos daneses, pues las quiero titular Novelas del Danés ${ }^{39}$.

Su determinación es clara: se niega a que el nombre de Juan Ramón Jiménez designe conjuntamente a un poeta y a un novelista. Para no desaprovechar todo el material novelístico que había ido atesorando, concibe el insólito plan de publicar sus libros como si fueran las traducciones al español de las obras de un autor danés. El nombre de este ficticio escritor nórdico le habría de servir como pseudónimo para ocultar el suyo propio. Nada de esto llegó a hacerse realidad. Lo único cierto fue que, con posterioridad a 1931, sus «bocetos» de novelas aún seguían pendientes de desarrollo. En 1953, Juan Ramón da a conocer una solución aún más sorprendente que la anterior. Estas fueron sus palabras:

(...) tengo muchos borradores de novelas que cedería gustoso a cualquier novelista que pudiera desarrollar asuntos novelescos ${ }^{40}$.

El hecho de ceder a otro sus «borradores» resulta tanto más desconcertante si se piensa que el poeta nunca hubiera permitido que otro escritor se adueñase de cualquiera de sus proyectos para sus libros de verso o prosa lírica. Cuando en la obra de otros vio destellos inequívocos de la suya, siempre estuvo pronto y alerta para señalarlo ${ }^{41}$.

Es evidente, pues, que Juan Ramón dispensó diferente tratamiento editorial a su creación poética y a su creación novelística - estuvo interesado en la publicación de la primera mientras que prescindió de la publicación de la segunda - y es evidente también que concedió distinta importancia a

${ }^{39}$ Juan Ramón de viva voz, I, ob. cit.,. p. 234. Con el título Novelas del Danés, pensaba el poeta formar una trilogía formada por los siguientes títulos ya citados: Hijo y obra, La muchacha y Cristo Padre.

${ }^{40}$ La corriente infinita, ob. cit., p. 248.

${ }^{41}$ Con esta rotundidad revindicaba la profunda huella que su obra dejó en la generaciones futuras: «Durante 25 años la poesía española ha sido (...) de Antonio Machado y mía. Todos los jóvenes me deben algo, muchos mucho, algunos casi todo (...) Ahora (...) empieza mi dominio en el reino de la prosa, que durará (....) otros 25 años» $(Y$ para recordar por qué he venido, ed. de J. Blasco Pascual, Valencia, Pre-Textos, 1990, p. 232).

El propio Juan Guerrero fue testigo del siguiente episodio: «(Juan Ramón) me enseña la revista DDOOSS que acaba de salir, comentando todo lo que hay suyo en los distintos poetas jóvenes (...) Para demostrar de dónde están cogidas diversas poesías de las que publica este número va viendo rápidamente en la Segunda Antología poética y en Poesía y Belleza los antecedentes claros, concretos, exactos, verso por verso» (Juan Ramón de viva voz, I, ob. cit., p. 114, nota del 9 de enero de 1931). 
su autoría - quiso figurar como poeta y se negó a aparecer como novelista-. Tan desigual consideración hacia una y otra faceta de su producción sólo puede achacarse a una valoración distinta de la poesía y de la novela. De todo lo expuesto, cabe deducir que otorgó al primer género mayor importancia que al segundo. En suma, el poeta estableció una relación jerárquica entre los dos géneros literarios: en el lugar principal situó a la lírica; en otro secundario, a la novela.

Indagando en el pensamiento del poeta, se llega a la conclúsión de que esta distinción entre poesía y novela se inscribe dentro del marco más amplio de su reflexión sobre el arte. A su juicio, no cabe atribuir el mismo valor a todas las expresiones artísticas. El poeta las clasifica en dos grupos, según se trate de «artes de creación» o de «artes de copia». He aquí sus palabras:

Yo creo que las artes (y las ciencias también) se dividen en artes de creación y artes de copia. Las de creación son, por ejemplo, la danza, la poesía y la metafísica escritas, más arte la metafísica que la ciencia; las de copia, la pintura, la escultura, la novela, por ejemplo. El teatro puede ser arte de creación, si es abstracto, de copia si es anecdótico ${ }^{42}$.

Así pues, la poesía figura entre las «artes de creación», junto a la danza y la metafísica; la novela forma parte de las «artes de copia», junto a la pintura y la escultura. El poeta es el artista mayor puesto que crea frente al novelista, que es artista menor, puesto que imita ${ }^{43}$. Juan Ramón quería ser reconocido como creador o poeta, no como imitador o novelista. Por eso, evitó aparecer en la portada de cualquiera de sus libros como tal.

Ahora bien, ¿qué particular concepción se forjó Juan Ramón de la novela para definirla como «arte de copia»? Para responder a esta pregunta se hace imprescindible averiguar cuáles fueron las obras y los autores leídos por el poeta y qué juicios le merecieron.

\section{LECTURAS Y JUICIOS DEL POETA SOBRE LA NOVELA}

La clasificación de la novela como «arte de copia» fue realizada por Juan Ramón en el transcurso de su conferencia «Poesía y Literatura», pro-

${ }^{42}$ El trabajo gustoso, ob. cit., pp. 37-38.

43 Afirma el poeta en un aforismo escrito en el año 1920: «Las artes imitativas son inferiores. El teatro para que tenga categoría excelsa no ha de imitar, ha de ser, existir, crear, como la poesía lírica o la música lírica» (Ideolojía, II, ob. cit., n. ${ }^{\circ}$ de aforismo 4171 , p. 13). Repárese en que el poeta considera al teatro «susceptible» de convertirse en «arte de creación», siempre y cuando reúna las condiciones por él señaladas. No contempla, sin embargo, la misma posibilidad para la novela, que a juicio del poeta no puede ser más que «arte de copia». 
nunciada en el año $1940^{44}$. Más de una década después, en 1953, vuelve a reafirmarse en esta misma opinión ${ }^{45}$. En suma, el poeta emite este juicio en la plenitud de su madurez creativa y crítica y lo sostiene y ratifica hasta el final de su vida. Debe ser considerado, pues, como la conclusión a la que llega tras muchas lecturas de novelas y tras reflexionar largamente sobre la situación del género en el pasado y en su propia época.

La dicotomía que establece entre «arte de copia/arte de creación»-de implicaciones aristotélicas - remite a una catalogación de los géneros basada en la relación que, en opinión del poeta, mantienen con la realidad. La novela - género adscrito a la primera clase - trata de imitar la realidad; la poesía - perteneciente a la segunda - persigue, por el contrario, crear su propia realidad. Este juicio del poeta, deja entrever lo mucho que condicionaron su visión de la novela sus lecturas de autores y obras realistas.

Entre la nómina de autores adscritoś por Juan Ramón a la «novela realista y naturalista», el poeta declaró haber leído a los siguientes novelistas españoles: Cervantes ${ }^{46}$, Juan Valera ${ }^{47}$, Clarín ${ }^{48}$, Emilia Pardo Bazán, Benito Pérez Galdós, José María de Pereda ${ }^{49}$ y Pío Baroja, el más próximo a

${ }^{44}$ El poeta, nacido en 1881, contaba entonces con 59 años de edad.

${ }^{45}$ La corriente infinita, ob. cit., p. 248.

${ }^{46} \mathrm{El}$ poeta no solo considera a Cervantes un «novelista realista» sino que, además, afirma refiriéndose a El Quijote: «Como obra realista, el libro de Cervantes no tiene par en ningún país, a no ser en Rusia, cuya literatura sólo conocemos a través de traducciones que no pueden dar nunca una idea completa» (Juan Ramón de viva voz, I, ob. cit., p. 302, nota del 19 de julio de 1931).

${ }^{47}$ En 1904, cuando el escritor todavía era una figura respetada y aun temida dentro de las letras españolas, Juan Ramón se atrevió a emitir este juicio demoledor sobre su obra crítica y novelística: «(...) don Juan Valera es un escritor de grandes galanuras gramaticales, frío, fino si se quiere, pero con la finura de una labor sin alma, hecha para el deleite de la mano: Nosotros nos hemos empeñado en decir que don Juan Valera es un perfecto ironista, en repetir que es esquisito, que es ático, que tiene una distinción misteriosa y un buen gusto excepcional (...). Y esta es la leyenda. En el fondo, don Juan Valera es un crítico de muy mediano gusto parado en Meléndez Valdés y en Nicasio Gallego, es un novelista que no sabe novelar, es un gran escritor artificioso y muy de gabinete. Cuando le dan el asunto, cuando le ofrecen el alma, él la viste muy bien con su egrejia gramática blanca por lo demás. Así es tan bella esa pastoral de Longo, en nuestra lengua de Castilla. Pero en sus obras falta todo esplendor: Pepita Jiménez y el Comendador Mendoza son tal vez sus dos libros que comienzan mejor: y ya veis, el segundo capítulo muere el novelista y sigue el escritor retórico y gramático» (cito por Primeras prosas, ed. de F. Garfias, Madrid, Aguilar, 1962, p. 123).

${ }^{48}$ De la obra cumbre del autor asturiano, dejó escrito Juan Ramón: «La Regenta, la novela de Oviedo, una gran novela», El modernismo (Notas de curso), ed. de Jorge Urrutia, Madrid, Visor Libros, 1999, p. 93.

${ }^{49} \mathrm{El}$ poeta declara que, en los primeros años del siglo $\mathrm{XX}$, estos tres autores fueron exaltados y leídos por él y por todos los jóvenes modernistas de entonces. Precisa, además, que dentro de la obra de Pereda gozó de más aprecio Sotileza que Peñas Arriba (ibidem, p. 93). 
él en el tiempo y, sin embargo, el más duramente juzgado ${ }^{50}$. De los grandes maestros del realismo europeo del siglo XIX, Juan Ramón dijo conocer a los franceses Émile Zola ${ }^{51}$ y Stendhal ${ }^{52}$ y a los rusos Fiodor Dostoievski ${ }^{53}$ y León Tolstoi ${ }^{54}$.

A partir de estas lecturas, el poeta reconstruye la historia del género en España: la novela surgiría, a su entender, en los inicios del siglo XVII de la mano de Cervantes, alcanzaría su apogeo en el siglo XIX, bajo la influencia de los grandes novelistas del realismo europeo, y llegaría hasta el siglo XX a través de la obra de autores como Baroja. El poeta se percata entonces de que, durante estos seis siglos, el «realismo» está presente en todo el proceso constitutivo de la novela española ${ }^{55}$. Tal constatación le obliga a ampliar el alcance del término. Desde su perspectiva, el vocablo «realismo» no designa únicamente el movimiento literario que tuvo su

${ }^{50}$ En el retrato que de él hizo para su libro Españoles de tres mundos dice acerca de su obra: "iQué angustia ver a un hombre que a los cincuenta años no sabe qué hacer, que dice que escribe porque se aburre, que pintarraquea las márgenes del libro de la vida, monigotes en los blancos de los libros!» (cito por Españoles de tres mundos, ed. de R. Gullón, Madrid, Aguilar, 1969, p. 352).

${ }^{51}$ El poeta menciona su novela Nana (cfr. El Modernismo (Notas de curso), ob. cit., p. 162)

${ }^{52}$ En concreto, hace referencia a las dos grandes obras del escritor francés: La Cartuja de Parma y Rojo y Negro (cfr. ibídem, p. 94).

${ }^{53}$ Juan Ramón realiza la siguiente reflexión sobre la influencia de la peripecia vital del escritor ruso en su vasta obra: «(...) epiléptico, martirizado en Siberia, sentenciado a muerte y salvado de la muerte a última hora. Estos hechos determinan fenómenos morbosos que tienen que encontrar desahogo frenético» (ibídem, p. 168).

${ }^{54}$ La admiración del poeta por Tolstoi fue mucho más allá de lo literario. Sentía por la vida y la personalidad del autor de Guerra y paz una gran fascinación hasta el punto de llegar a equipararle en importancia con otros grandes personajes de la historia como el mismo Cristo o Gandhi (ver ibídem, p. 160). Entre sus proyectos estaba el de escribir una biografía del escritor ruso que habría de aparecer dentro de la colección Vida de hombres ilustres, promovida 1915 por la editorial de la Residencia de Estudiantes. De esta intención, dejó constancia el poeta en numerosas anotaciones manuscritas localizadas en el Archivo Histórico Nacional de Madrid (signaturas 59/146, 59/81, 156/110, 156/ $249,156 / 270,156 / 337,156 / 410$ y $283 / 2$ ) y en la «Sala Zenobia-Juan Ramón Jiménez» de la Universidad de Puerto Rico (Proyectos 4, 48).

${ }^{55} \mathrm{Y}$ es que, a juicio del poeta, el «realismo» está profundamente enraizado en el ser español. En uno de sus aforismo, afirma: «(...) el español es realista. Y la excepción de los místicos huidores no hace más que confirmar la regla» (Ideolojía, ob. cit., aforismo n. ${ }^{\circ} 3226$, p. 545). En otra ocasión, reitera Juan Ramón: «(...) España, país hondamente realista» (El trabajo gustoso, ob. cit., p. 41). El propio Benito Pérez Galdós, uno de las grandes novelistas realistas leídos por Juan Ramón, era de la misma opinión del poeta. En el prólogo que escribió para La Regenta de Clarín, afirma refiriéndose al naturalismo: «(...) todo lo esencial del Naturalismo lo teníamos en casa desde tiempos remotos, y antiguos y modernos conocían ya la soberana ley de ajustar las ficciones del arte a la realidad de la naturaleza y del alma, representando cosas y personas, caracteres y lugares como Dios los ha hecho» (cito por La Regenta, Madrid, Ediciones Akal, 1985, p. 10). 
origen y vigencia en la segunda mitad del siglo XIX sino que alude a un rasgo inherente al propio género, el que convierte la novela en «arte» que «copia» la realidad. Por esta razón, para el poeta, la novela canónica, la novela en sentido estricto, es la novela realista.

Como lector, Juan Ramón gustó de adentrarse por las páginas de estas obras y transitar por los ambientes que con tanto esmero lograron reconstruir sus autores; pero, como poeta empeñado en escribir sus propias novelas, se apartó radicalmente del modelo estético que representaban. La razón es clara: el de Moguer halló incompatibilidades insalvables entre su poética y la estética de la novela realista. Téngase en cuenta que en 1918, fecha en que concibió Desnudos (o Verde y alegre), el primer proyecto novelístico del que se tiene noticia, su ideario poético estaba ya nítidamente definido ${ }^{56}$. El autor, que se había propuesto el difícil reto de escribir novelas sin abdicar de su condición de poeta, no podía incurrir en contradicción con sus principios poéticos. Sus posibles novelas debían ser una prolongación de su poesía y, por tanto, debían supeditarse a las mismas normas estéticas que aquélla ${ }^{57}$. Al comprobar que la novela realista no se avenía con su credo estético, la desechó como modelo estético a seguir en el desarrollo de sus propios proyectos. Para comprender esta decisión del poeta, conviene conocer los principales puntos de disensión entre la poética juanramoniana y la estética realista.

La primera y más grave discordancia se produce a la hora de definir el término «realismo». Juan Ramón repara en que el vocablo se presta no a una sino a varias interpretaciones, por lo que siente la necesidad de dejar bien clara cuál es la suya, no sin antes declararse abiertamente «realista». He aquí sus palabras:

Sí, soy un realista; pero ¡qué diferencia entre «realismos»y «realismos»! Poniendo a la mujer desnuda como símbolo del realismo se comprenderá cómo puedo yo ser realista y cómo puedo ser enemigo de otros... realistas ${ }^{58}$.

En la «realidad», entendida como entorno, como vida circundante, encontró la materia necesaria para esbozar sus proyectos de novelas. No buscó

\footnotetext{
${ }^{56}$ A juicio de J. Blasco Pascual, el poeta alcanza su «madurez» poética con el poemario Estío (1916) y su «plenitud» con Diario de un poeta reciencasado (1917) (cfr. «Prólogo» a su Antología poética, Madrid, Cátedra, 1993, p. 61). C. Lapeña considera, incluso, que Juan Ramón elige Desnudos como título de su proyecto novelístico para ponerlo en relación con la «poesía desnuda» de su Diario (cfr. «Sobre un proyecto narrativo de Juan Ramón», art. cit., p. III).

57 Otro poeta, Pedro Salinas, resumió con acierto el particular proceder del andaluz: «Para Juan Ramón Jiménez, la poesía, la vis creativa opera con la misma dignidad, con el mismo rango y altura en toda obra donde se halla presente. La poesía no es cosa de géneros, es pura esencia. Y donde alienta ella está presente el poeta entero» («Sucesión de Juan Ramón Jiménez (1932)» en Literatura española. Siglo XX, Madrid, Alianza, 1972, p. 146).

${ }^{58}$ Ideolojía, ob. cit., n. ${ }^{\circ}$ de aforismo 1828, p. 302.
} 
en otras épocas, ni tampoco exploró lugares, ambientes o caracteres humanos que no fueran los que asiduamente frecuentaba. Fijó su mirada en la «realidad» y no cesó de revindicarla como «fuente» de su escritura. Basten unas cuantas sentencias suyas para confirmarlo:

Yo pienso que este mundo es nuestro único mundo, y que en él y con lo suyo, hemos de realizarlo todo ${ }^{59}$.

La divina realidad ${ }^{60}$.

No dibujemos inútiles caprichos al marjen de la realidad ${ }^{61}$.

Hasta aquí su proceder coincide con el de los novelistas realistas. Ahora bien, Juan Ramón se aparta definitivamente de ellos en dos cuestiones fundamentales: en la percepción de la realidad y en su representación estética. Para los novelistas del realismo, el universo que les rodea constituye una unidad significativa. Cada uno de los innumerables elementos que lo componen encierra una enseñanza sobre el «todo». Por eso, la perspectiva que adopta el novelista realista es analítica: disecciona y examina racionalmente la realidad en todas sus partes ${ }^{62}$. A esta perspectiva analítica le corresponde una estética de reproducción o «copia» ${ }^{63}$. El novelista trata de contar la anécdota o asunto de su obra siguiendo un desarrollo lineal y verosímil, acorde al discurrir de los acontecimientos en el mundo real. Con la misma intención mimética, se esmera por describir el universo y los personajes de su libro. En definitiva, la «anécdota» y la «descripción» marcan, en opinión de Juan Ramón, la estética de la novela realista.

${ }^{59}$ Ibídem, $\mathrm{n} .^{\circ}$ de aforismo 3253 , p. 552.

${ }^{60}$ Ibídem, n. $^{\circ}$ de aforismo 1542 , p. 262.

${ }^{61}$ Ibídem, n. ${ }^{\circ}$ de aforismo 1578 , p. 266.

En libros de verso cercanos a la fecha en que inicia sus proyectos novelísticos, como es el caso de Eternidades (1917), el poeta sigue exaltando la «realidad»: "Aquella que creía gloria cerrada,/ era la puerta abierta/ para esta claridad./ ¡Campo sin nombre!/ ¡Camino inestinguible/ de puertas sucesivas,/ siempre a la realidad/ ¡Vida sin cuento!/» (cito por Libros de poesía de Juan Ramón Jiménez, ed. de Agustín Caballero, Madrid, Aguilar, 1972, p. 570)

${ }^{62}$ En su libro Existentialisme ou Marxisme, el crítico Georg Lukács define en los siguientes términos esta concepción de la realidad de raíz marxista: «(...) la categoría de la Totalidad significa, de una parte: que la realidad objetiva es un todo coherente en el que cada elemento está, de una manera o de otra, en relación con cada elemento; y de otra parte, que estas relaciones forman en la misma realidad objetiva, correlaciones concretas, conjuntos, unidades, ligados entre ellas de maneras diversas, pero siempre determinadas» (cito por Juan Ignacio FERRERAS, Teoría y praxis de la novela. La última aventura de don Quijote, París, Ediciones Hispano-Americanas, 1970, p. 11).

${ }^{63} \mathrm{Tal}$ y como sostiene Juan Ignacio Ferreras, «para el novelista «tradicionalmente» realista, el problema de la realidad acaba (...) por presentarse como un puro problema técnico; se trata nada más y nada menos, de reproducir o materializar su visión del universo; aunque naturalmente, el «realista» cree que lo que reproduce es $e l$ universo y no $s u$ universo (ibídem, p. 15). 
Sobre estos presupuestos, el poeta realiza una crítica en profundidad al realismo en la novela. Para empezar, no concibe la realidad como una unidad de significado sino que la divide en dos planos ontológicos distintos: la «realidad visible» y la «realidad invisible». El primer plano o «realidad visible» se corresponde con el entorno que el poeta percibe a través de sus sentidos y conoce a través de su razón. En definitiva, se trata de la misma realidad que los novelistas realistas se afanaron por inspeccionar. El segundo plano o «realidad invisible» no es perceptible a través de los sentidos ni tampoco puede conocerse a través de la razón. En contra de lo que se pudiera inferir, el poeta advierte que esta otra «realidad» no existe al margen de la «visible» sino que está «sustentada» y «arraigada» en ella. Para ascender a lo «invisible» tan sólo es necesario tener deseo y voluntad de encontrarse con lo «ideal». De esta manera lo explica Juan Ramón:

La verdadera poesía (...) es la que estando sustentada en la realidad visible, anhela, ascendiendo, la realidad invisible; enlace de raíz y a la que, a veces, se truecan; la que aspira al mundo total, fundiendo, como en el mundo total, evidencia e imajinación ${ }^{64}$.

Cuando se mira lo «real visible» con la intención de hallar «lo ideal», los objetos y seres corrientes cobran una nueva vida, alcanzan su «plenitud de sentido» ${ }^{65}$. Y es que la mirada del poeta les contagia su deseo de infinitud y belleza. Su mirada ejerce, pues, un poder transformador sobre la «realidad visible». Para explicar el modo en que funciona la «percepción mágica» desde la que contempla cada ser y cada objeto, Juan Ramón se sirve del símbolo del «calidoscopio». Del mismo modo que cuando era niño le bastaba mirar a través de los cristales de su «calidoscopio» para encontrar belleza a su alrededor ${ }^{66}$, ya de adulto le era suficiente con mirar a través de su «imajinación»y su «sentimiento» ${ }^{67}$.

${ }^{64}$ El trabajo gustoso, ob. cit., p. 58.

${ }^{65}$ Cfr. J. Blasco Pascual, Poética de Juan Ramón Jiménez, Universidad de Salamanca, 1981, p. 234.

${ }^{66}$ Dentro de su libro Josefito Figuraciones, se encuentra el siguiente ejemplo: Josefito, que es Juan Ramón de niño, observa con estupor cómo una dalia «feona» se transforma en una flor de belleza deslumbrante cuando la contempla a través de su «calidoscopio»: «La abundancia de cristales, oscura piña, dramático rosetón cargado y como pegado que tenía el calidoscopio al cojerlo él aquel día, aquella morada negra dalia aceitunosa prieta feona, que aparecía tantas veces y a él le gustaba tan poco, quedó convertida por no sabía qué májico escamoteo súbito, en una leve, delgadísima, casi ausente flor de hilos amarillentos, blancotes, verdines, que la espléndida luz estrellada de oro chispa de la tarde agua y sol de carnaval, trasparentaba musicalmente sobre el opaco cielo redondo del fondo» (cito por Elejías andaluzas, ed. de Arturo del Villar, Barcelona, Seix Barral, 1994, pp. 131-132).

${ }^{67}$ En unos de sus aforismos, afirma el poeta: ${ }$ El Arte? La realidad vista con sentimiento. La mentira vista con imaginación» (Ideolojía, ob. cit., n. ${ }^{\circ}$ de aforismo 1924, p. 315). En otro, declara: «Tengo por cabeza un calidoscopio» (ibídem, $\mathrm{n}^{\circ}{ }^{\circ}$ de aforismo 1664, p. 279). 
La «realidad visible» es, pues, la pantalla sobre la que se proyecta lo «ideal» siempre y cuando se sepa mirar. Por eso, afirma el poeta:

«¿Realismo májico?» Todo realismo lo es. Somos nosotros los que podemos ser o no májicos ${ }^{68}$.

Llegados a este punto, ya puede decirse que lo que separa a Juan Ramón de los novelistas realistas no es la negación de la «realidad visible» ${ }^{69}$ sino su inconformismo con ella. El poeta siente la ineludible necesidad de ampliar y enriquecer «lo real visible» para no quedar atrapado en sus estrechos márgenes. Por eso, emprende la conquista de nuevos ámbitos de la «realidad», ámbitos desconocidos e «invisibles» que sólo puede clariver a través de su mirada «májica». Con estas palabras resume el poeta su proceder:

Si el poeta (el hombre) 'se contenta con la realidad visible para su canto exaltado, no pasará de ahí, esa realidad es su vida. Si piensa y sueña y espresa otras realidades, las invisibles, que él clarivé, su expresión, su pensamiento, su sueño quizás cuaje $(\ldots)^{70}$

En definitiva, frente a la perspectiva analítica y racional de los novelistas realistas, Juan Ramón opone su perspectiva «májica» y subjetiva. A dos maneras tan dispares de abordar la realidad les corresponden dos representaciones estéticas igualmente antagónicas. Frente a la estética de «copia» de los novelistas realistas, Juan Ramón propone una estética de «creación» ${ }^{71}$. Para los novelistas del realismo, la realidad precede y condi-

${ }^{68}$ Ibídem, aforismo n. ${ }^{\circ} 2792$, p. 452 . En otro aforismo, suscribe la misma idea: «No importa «lo que se ve», sino «desde donde se ve» (ibídem, aforismo n. ${ }^{\circ} 4665$, p. 117). Estas palabras del poeta evidencian la influencia que tuvieron sobre su poética Ortega y Gasset y su teoría del «perspectivismo vital». El filósofo madrileño inculcó al poeta, al igual que otros muchos hombres de su generación, la idea de que «cada vida es un punto de vista sobre el universo». Aborda este aspecto de la poética juanramoniana, J. Blasco Pascual en Poética de Juan Ramón Jiménez, ob. cit., pp. 148-150.

${ }^{69}$ Como aquellos, Juan Ramón la reafirma. Es más, a medida que va madurando, su apego -a «lo real visible» fue cada vez mayor. Sirva esta declaración suya para confirmarlo: «Cuando yo tenía 17, 18, 19 años, evitaba el detalle realista en mi escritura, o lo cubría con velos más o menos ideales. Hacia lo mismo que veía hacer en la vida, porque yo no sabía entonces que lo más ideal es nada sin lo más real de donde sale como verdad de contraste (...)» (Ideolojía, ob. cit., n. ${ }^{\circ}$ de aforismo 3845, p. 679).

${ }^{70}$ Ibídem, n. ${ }^{\circ}$ de aforismo 3249, p. 550.

71 Esta distinción que Juan Ramón establece entre estética de «copia» y estética de «creación» coincide con los dos tipos de «realismo» («realismo genético»o «de correspondencia» y «realismo formal») que señala Darío Villanueva al estudiar la historia y evolución del término en la literatura. He aquí el juicio del crítico: «Lo que importa es encontrar una concepción del realismo en literatura que alcance un punto de equilibrio entre el principio de autonomía de la obra literaria frente a las determinaciones de la realidad (...) En el realismo genético o «de correspondencia», todo se fía a la existencia de una realidad unívoca, anterior al texto, ante la que se sitúa la conciencia del autor, 
ciona su lenguaje, por eso, ésta ha de imitarla y someterse a sus reglas; para Juan Ramón, la realidad no existe antes de su palabra sino que es ésta la que la crea ${ }^{72}$. Primero, el poeta descubre lo «invisible»o «májico» que se oculta tras lo «visible», después, por medio de su palabra poética, lo dota de forma. Al hacerse forma, es decir palabra, cobra vida. Lo que antes era «invisible» e informe comienza a existir nada más ser nombrado por el poeta y esta nueva existencia redunda en enriquecimiento y ampliación de lo real.

Juan Ramón comprende, entonces, que escribir sus novelas conforme a su estética de «creación» le exigiría, en primer lugar, derribar el eje sobre el que los novelistas realistas sustentaban la construcción de sus obras. Si éstos tomaban como componente fundamental de sus novelas la «historia» o argumento, él elige el lenguaje como el elemento primordial ${ }^{73}$. El poeta rechaza, de este modo, la subordinación de la palabra a la «historia» y aún radicaliza más su postura al abogar por la supresión de todo argumento o relación de hechos. De este modo lo indica en este aforismo:

escudriñadora de todos sus entresijos mediante una demorada y eficaz observación. Todo ello dará como resultado una reproducción veraz de aquel referente, gracias a la transparencia o adelgazamiento del medio expresivo de la literatura, el lenguaje (...) Este segundo realismo (el «formal») resulta, más que de la imitación o correspondencia, de la creación imaginativa que depura aquellos materiales objetivos que podrían estar en el origen de todo el proceso, y los somete a un principio de coherencia inmanente que les hará significar, más por vía del extrañamiento que por la de la identificación de la propia realidad factual» («Fenomenología y pragmática del realismo literario» en Avances en Teoría de la literatura, Universidad de Santiago, 1994, pp. 165-185; pp. 167-168).

La fidelidad a sus principios poéticos lleva a Juan Ramón a adherirse a la segunda concepción de «realismo», la llamada «realismo formal» (según la terminología empleada por D. Villanueva) o estética «de creación» (según la terminología empleada por el propio poeta).

${ }_{72}$ El valor fundacional y creador que Juan Ramón otorga a la palabra poética queda perfectamente expresado en este poema escrito en 1911: «Creemos los nombres./ Derivarán los hombres./ Luego, derivarán las cosas./ Y sólo quedará el mundo de los nombres,/ del olor de las rosas.// Del amor y las rosas/ no ha de quedar sino los nombres./ ¡Creemos los nombres!» (Cito por Selección poética, ed. de Fernando Gómez Redondo, Madrid, Alambra, 1991, p. 108).

Adviértase que estos versos datan de siete años antes que Desnudos, su primer proyecto de novela.

${ }^{73}$ Utilizo la terminología que establece Fernando Gómez Redondo para diferenciar los tres elementos fundamentales que intervienen en el proceso narrarivo descrito por el autor del siguiente modo: «Un escritor opera con unos moldes lingüísticos a los que transforma desde una determinada voluntad estilística (narración); con ellos va construyendo una representación textual (relato) en la que alberga las distintas líneas argumentales (historia) que dan existencia a la realidad narrativa. Éstas son las tres instancias que existen en cualquier novela: 1) el plano del estilo (narración), 2) la estructura narrativa (relato) y 3 ) el argumento (historia)» («El discurso narrativo» en El lenguaje literario. Teoría y práctica, Madrid, Edaf, 1994, pp. 125-246; pp. 138-139). 
No me gusta el hecho, sino su representación; porque en el hecho soy yo el partícipe o espectador solamente, y en la representación soy creador, es decir, poeta $^{74}$.

Escribir novelas carentes de «historia» o anécdota: ése es el ideal que se marca el poeta. Incluso, insta a seguir por el mismo camino a la nueva generación de novelistas españoles que había surgido en la posguerra. Así se pone de manifiesto en una carta que Juan Ramón dirige en 1946, desde su exilio en Washington, a Carmen Laforet. Tras leer Nada, primera novela de la autora, el poeta le comenta cómo el libro pierde intensidad justamente en aquellos capítulos en los que más se detiene en desarrollar la trama. De este modo recrimina a la joven novelista de entonces:

Nada tropieza en el capítulo 19, es decir cuando se declara una trama novelesca seguida. Yo no he leído ese capítulo, me repugnaba; y tardé después algún tiempo en terminar lo que quedaba del libro, porque aquel capítulo me hacía el efecto de un nudo como el un cólico misere, que pudo quitarle la vida al resto. Porque usted es novelista de novela sin asunto, como se es poeta de poema sin asunto. $\mathrm{Y}$ en esto está lo más difícil de la escritura novelesca o poemática ${ }^{75}$.

Seguidamente, le lanza el siguiente desafío:

(....) a ver cómo coje usted ese difícil Madrid en otra novela sin asunto ${ }^{76}$

Si se elimina la «historia» o anécdota, la novela no precisa ya de desarrollo argumental alguno, razón por la cual Juan Ramón decide prescindir también de la estructura narrativa o «relato». Puesto que renuncia a contar hechos, le parece totalmente innecesario construir sus posibles novelas de acuerdo a un plan organizativo que haga las veces de hilo conductor $\mathrm{y}$ encadenador de los acontecimientos. El poeta confiesa desdeñar la «composición» tanto como el «asunto»:

Yo he desdeñado siempre - afirma-, y más cada día, «el asunto» y «la composición». Lo que siempre me tienta es la sensación que un fenómeno produ-

${ }^{74}$ Ideolojía, ob. cit., § 1475, p. 253.

En una anotación manuscrita que se conserva en la Sala Zenobia-Juan Ramón Jiménez de la Universidad de Puerto Rico (signatura Proyectos 2, 65) dejó escrito el poeta refiriéndose a sus libros de «prosa lírica»: «Nada anecdótico, o lo imprescindible».

${ }^{75}$ Cartas. Antología, ed. de F. Garfias, Madrid, Espasa-Calpe, 1990, p. 266.

Juan Ramón también se consideraba a sí mismo un poeta «sin asunto». Así lo declaró en el «Prólogo» al poema Espacio: «(...) toda mi vida he acariciado la idea de un poema seguido (¿cuántos milímetros, metros, kilómetros?) sin asunto concreto, sostenido sólo por la sorpresa, el ritmo, el hallazgo, la luz, la ilusión sucesiva, es decir, por sus elementos intrínsecos, por su esencia (...) sucesión de hermosura más o menos inesplicable y deleitosa» (cito por En el otro costado, ed. de Aurora de Albornoz, Madrid, Júcar, 1974, p. 129).

${ }_{76}$ Cartas. Antología, ob. cit., p. 269. 
ce, la inquietud pensativa y sensitiva que queda después del asunto y antes de la composición; y lo que me interesa es libertar sensación e inquietud ${ }^{77}$.

Cada vez se va mostrando más nítido el ideal del poeta: excluidos la «historia» (el «asunto» según su terminología) y el «relato» (la «composición»), sus novelas habían de sustentarse única y exclusivamente en el lenguaje. Era la forma la que debía conferir a sus libros la trabazón que los realistas confiaban al contenido o trama argumental. Juan Ramón se jacta de lo arriesgado y difícil del reto que se había propuesto:

¿Qué bello - y qué difícil- mantener sin rotura ese hilo de nada que ata por dentro un libro así, irlo devanando puro, claro y limpio, y dándole en su levedad consistencia para lo eterno! ${ }^{78}$

Toda la revisión crítica de la novela realista, realizada siempre desde su pensamiento poético, lleva al poeta á tomar conciencia de la necesidad de buscar una nueva manera de hacer novelas. A su juicio, tal renovación habría de basarse, claro está, en la revalorización del lenguaje como elemento principal del proceso narrativo. Aunque partiendo de otros planteamientos estéticos, los principales novelistas de principios del siglo $\mathrm{XX}$, habían llegado a la misma conclusión que Juan Ramón. El poeta comparte con autores como Valle-Inclán, Miró o Ramón Pérez de Ayala la misma actitud de rechazo a la novela realista y el mismo deseo de renovación formal.

Esta tendencia renovadora, denominada «novela formalista», se inició con el modernismo y se prolongó hasta la Guerra Civil ${ }^{79}$. Durante estas tres décadas, Juan Ramón siguió muy atentamente la evolución de la novela española ${ }^{80}$. Leyó y enjuició desde su particular posición de poeta interesado en escribir novelas la obra de los autores más innovadores de su tiempo. El aspecto sobre el que primero reparó fue, claro está, el del esti$10{ }^{81}$. Consideraba Juan Ramón que los novelistas del realismo habían llevado la prosa española a un estado lamentable de descuido y desaliño ${ }^{82}$.

${ }^{77}$ La corriente infinita, ob. cit., p. 177.

${ }^{78}$ Ideolojía, II, ob. cit., n. ${ }^{\circ}$ de aforismo 4175, p. 14.

${ }^{79}$ Define esta tendencia renovadora y revisa su trayectoria y sus principales cultivadores Juan Ignacio Ferreras en «La novela formalista», La novela en el siglo XX (hasta 1939), Madrid, Taurus, 1990, pp. 71-89.

${ }^{80}$ Sin embargo, el poeta confiesa, en la ya mencionada carta a Carmen Laforet, que su seguimiento de la novela española se interrumpe con el exilio: «De los más jóvenes novelistas españoles que viven en España, y que se citan tanto, no he conseguido ver ningún libro. De los que viven fuera, ninguno ha publicado novelas dignas de hablar de ellas que yo sepa» (Cartas. Antología, ob. cit., p. 267)

${ }^{81}$ Declara el poeta: «Siempre me ha obsesionado este asunto del estilo» (ibídem, p. 267).

${ }^{82}$ Esta fue la dura crítica que les hizo Juan Ramón: «¿Qué es un estilo cuidado? ¿En qué consiste ese cuidado? Los estilos que se han venido usando en gran parte de la 
Por eso, la tarea más urgente que había que acometer era la de devolver a la prosa su belleza formal. Aunque el poeta valoró la meritoria búsqueda estética que emprendieron muchos de sus coetáneos, ejerció de crítico implacable de sus obras. Sobre cada uno de los novelistas renovadores antes citados, emitió el poeta su severo veredicto. A Ramón del Valle-Inclán, Juan Ramón le reprochó el exceso de cursilería en que incurre la prosa modernista de sus Sonatas ${ }^{83}$. De igual manera, califica de "preciosista y amanerado» el estilo de su novela Tirano Banderas ${ }^{84}$. Sin embargo, el poeta alaba con entusiasmo la prosa de otras de sus novelas esperpénticas por su «plenitud de sintaxis, dicción y de acento» ${ }^{85}$.

A Gabriel Miró, otro de los grandes renovadores formales de la novela de principios del siglo XX, le reconoce Juan Ramón su denodado esfuerzo por dotar a la prosa de valores, no sólo líricos, sino también musicales y pictóricos ${ }^{86}$. Pero, en su empeño por impregnar su escritura de sensaciones y emociones a través de un vocabulario exuberante y del uso frecuente de metáforas, no pudo evitar caer en un estilo barroco y recargado totalmente contrario a su ideal de sencillez ${ }^{87}$. De los libros que leyó del escritor alicantino, Juan Ramón considera intentos fallidos de renovación Hilván de escenas $(1903)^{88}$, Nómada $(1908)^{89}$ y Figuras de la Pasión $(1916)^{90}$. Tan sólo salva de su riguroso escrutinio, la novela El libro de Sigüenza $(1917)^{91}$.

Los esfuerzos estilísticos de Ramón Pérez de Ayala le parecieron total-

novela española contemporánea, no responden a estas preguntas ¡Qué estilos! El de Pedro Antonio de Alarcón, morroñoso, sin gracia, como una sucia jitana desgarbada, y que se ha supuesto natural y vivo; el de Juan Valera, vacío y pedante a un tiempo, como un mal vaciado de escayola de un mármol bello; el de Armando Palacio Valdés, la vulgaridad burguesa más insoportable (...)» (ibídem, p. 267).

${ }^{83}$ Sobre este particular comenta el poeta: «El final del siglo XIX y el comienzo del $\mathrm{XX}$ fueron, en su esteticismo general, verdaderamente cursis, es decir, decían lo que no era verdad. Valle sigue moviéndose en los fondos del Epitalamio y la Sonata de otoño, más D'Annunzio que Barbey o Casanova; sólo que ahora los tiene, los usa, los estropea, son suyos» («Ramón del Valle-Inclán (Castillo de quema)» en La corriente infinita, ob. cit., pp. 96-97)

${ }^{84}$ Cfr. Cartas. Antología, ob. cit., p. 81

${ }^{85}$ Cfr. Ibídem, p. 81 y también El Modernismo. Notas de curso, ob. cit., p. 130.

${ }^{86}$ Cfr. Juan Ramón de viva voz, I, ob. cit., p. 64, nota del día 1 de junio de 1931.

${ }^{87}$ Cfr. El Modernismo. Notas de curso, ob. cit., p. 88.

${ }^{88}$ El poeta lo tacha de «libro de papel estraza, muy malo y con un título terrible» (Juan Ramón de viva voz, $I$, ob. cit., p. 63, nota del día 1 de junio de 1931).

${ }^{89}$ Apunta Juan Guerrero en su libro: «(...) tampoco le gustó aquella narración de tipo maeterliniano y misterioso» (ibídem, 63).

${ }^{90}$ Comenta el poeta: «Cuando se publicaron las Figuras de la Pasión con aquellos ditirambos, encontré que en la descripción de Jerusalem, por ejemplo, la prosa parecía demasiado tomada de una enciclopedia, de una geografía» (ibídem, 64).

${ }_{91}$ Juan Guerrero escucha de boca del poeta que «esto fue lo primero que le gustó de Miró. Entonces fue cuando existió alguna relación entre ellos» (ibídem, 63). 
mente baldíos. Para el poeta, el novelista no consiguió más que escribir una prosa «académica, hábil, fría seca», «sin derrame ni contajio» ${ }^{92}$.

A Juan Ramón tampoco se le oculta que renovar el género de la novela exigía ir mucho más allá de la simple depuración estilística. La nueva novela habría de reflejar también los cambios que se habían producido en la forma de percibir la realidad con respecto al período realista y naturalista. Puesto que en el pensamiento de las primeras décadas del siglo XX, se impone la idea de que cada hombre representa una forma de percibir el universo ${ }^{93}$, la nueva novela había de traslucir en su configuración la particular percepción de su autor. Se trata, pues, de una novela subjetiva en la que los hechos se subordinan a las sensaciones y emociones que la realidad despierta en el sujeto. Entre los representantes de este «subjetivismo estético», Azorín fue el novelista más leído y conocido por Juan Ramón. En su obra, el poeta de Moguer pudo encontrar los rasgos más característicos de ese «nuevo arte» de escribir novelas: la «sucesión temporal rota por la tenaz discontinuidad del estilo» - de manera que la obra se compone de «breves capitulitos voluntariamente deshilvanados»-, la «inacción temática» - novelas en las que parece no ocurrir nunca nada-, «la generalización del presente del verbo», «las frases nominales» en detrimento de los verbos que denotan actividad y movimiento ${ }^{94}$.

Juan Ramón tuvo temprano conocimiento de la obra de Azorín. En el año 1903, el poeta escribe una encomiástica reseña sobre Antonio Azorín en la revista Helios, libro que junto con La voluntad y Las confesiones de un pequeño filósofo forma la trilogía protagonizada por el personaje del que José Martínez Ruiz adoptará su pseudónimo. El poeta, que entonces contaba con 22 años, elogia con ardor juvenil la maestría de la prosa azoriniana, que aunque «castellana» y sobria, es capaz de mostrar «emociones nuevas» ${ }^{95}$. Con el paso de los años, este primer entusiasmo por la novela de Azorín se va atemperando hasta que en 1931, el poeta confiesa a Juan Guerrero que «lo mejor» de Azorín quedó, sin solución de conti-

${ }^{92}$ Españoles de tres mundos, ob. cit., p. 160.

${ }_{93}$ Recuérdese que fue sobre todo Ortega y Gassset quien difundió esta idea en la estética de su tiempo (volver a ver nota 68 del presente artículo).

${ }^{94}$ Cfr. Antonio RISCO, «La novela de Azorín y el «Nouveau Roman» francés», Revista Canadiense de Estudios Hispánicos, 1 (otoño de 1976), pp. 75-98; p. 90. A juicio del citado estudioso, todos estos rasgos convierten a Azorín en un anticipador del «Nouveau Roman» francés. El citado estudioso explica la indudable semejanza que existe entre la novela azoriniana y la francesa por compartir el escritor alicantino fuentes literarias comunes con los novelistas franceses (cita como ejemplos a los hermanos Goncourt, Proust, Joyce) y por haber recibido las mismas influencias filosóficas que aquellos (Kant, Berkeley, Schopenhauer y Nietzsche), influencias que, como en los franceses, dejaron en el pensamiento del de Monóvar la concepción cíclica del tiempo (ibídem, p. 75).

95 Ver Prosas críticas, ed. de Pilar Gómez Bedate, Madrid, Taurus, 1981, pp. 47-48. 
nuidad, en sus primeros libros ${ }^{96}$. En los últimos años de su vida, el poeta parece recuperar el aprecio por la obra del novelista alicantino, contradiciendo su opinión anterior al afirmar que «Azorín (...) escribe más bien cada vez» ${ }^{97}$.

Para completar los conocimientos del poeta sobre las nuevas tendencias de la novela española de principios del siglo $\mathrm{XX}$, falta por mencionar su interés por la «novela intelectual» y, en particular, por uno de sus grandes cultivadores, Miguel de Unamuno ${ }^{98}$. Sin embargo, a pesar de la admiración que durante toda su vida sintió por la obra y el pensamiento del escritor vasco, Juan Ramón considera que lo más valioso de Unamuno está en su poesía, no en sus novelas. En opinión del poeta, ni siquiera Niebla, su obra más innovadora y arriesgada, conseguía vencer el paso del tiempo ${ }^{99}$.

El exhaustivo seguimiento que Juan Ramón hizo del género le llevó a leer también las obras de los novelistas más destacados de fuera de España. Entre los europeos, el poeta reconoce haber leído a Marcel Proust ${ }^{100}$ y a James Joyce ${ }^{101}$. A este último, Juan Ramón se atreve a disputarle el título de iniciador del «monólogo interior» que tradicionalmente se le había otorgado. Incluso, el poeta duda de que pueda considerarse innovadora una técnica basada en el libre discurrir del pensamiento; mecanismo que, en su opinión, funciona de manera natural y cotidiana en todo hombre ${ }^{102}$. Asimismo, niega que sea el Ulysses la obra en que se utiliza por primera vez

${ }^{96}$ Juan Ramón de viva voz, I, ob. cit., p. 71, nota del día 9 de julio de 1930.

97 Cartas. Antología, ob. cit., p. 267.

${ }^{98}$ Recuérdese que en 1930, Juan Ramón tenía en mente el proyecto de escribir seis «novelas intelectuales de tamaño grande» (volver a ver nota 14 del presente artículo).

${ }^{99}$ Cfr. Juan Ramón de viva voz, I, ob. cit., p. 130. La misma valoración le merece el teatro unamuniano: «Su teatro -afirma el poeta- peca de predicación; el teatro no se hace para discutir de filosofía» (ibídem, p. 130).

${ }_{100}$ Del escritor francés dice poseer su obra completa (cfr. Juan Ramón de viva voz, II, ob. cit., p. 268, nota del día 27 de noviembre de 1934).

101 Juan Ramón mostró gran interés por el escritor irlandés a lo largo de toda su vida. Además de conocer su obra narrativa, se sabe con certeza que el poeta leyó su poesía (cfr. ibídem, 268) y estudios críticos sobre el novelista. En el diario que escribió Zenobia Camprubí durante la estancia del matrimonio en Estados Unidos, queda registrado cómo la esposa del poeta le tradujo un «largo artículo sobre Joyce» aparecido en el Times (cfr. Diario, 2 Estados Unidos (1939-1950), trad. y notas de Graciela Palau de Nemes, Madrid, Alianza-Editorial de la Universidad de Puerto Rico, 1995, p. 56) así como las críticas a una biografía de Joyce que encontró en el Sunday Times (ibídem, p. 190)

${ }_{102}$ De esto modo lo explica el poeta: «El monólogo interior de Joyce consiste en dejarse, ir, sin voluntad, con un pensamiento disperso; lo que hacemos todos, todos los días. Cuando uno está en su casa, después de almorzar, se toma una taza de café, se sienta en una butaca, pues divaga la voluntad y se pone uno a acordarse de cosas y uno mezcla París y Rusia y las ideas políticas y el crimen de tal sitio; todo eso viene unido. Eso es el monólogo interior» (El Modernismo. Notas de curso, ob. cit., p. 89). 
este procedimiento narrativo y revindica el empleo que él mismo hizo del «monólogo interior» en las prosas de Diario de un poeta reciencasado, libro publicado en 1916, seis años antes de que viera la luz la célebre novela de Joyce ${ }^{103}$.

De los novelistas del otro lado de Atlántico, Juan Ramón confesó su interés por John Steinbeck y por Ernest Hemingway ${ }^{104}$. Entre los hispanoamericanos, el poeta elogia vivamente la «novela indigenista» de Ricardo Güiraldes, Don Segundo Sombra ${ }^{105}$. Con igual entusiasmo, agradece a Jorge Luis Borges, en una carta fechada el 12 de noviembre de 1949, la novedad absoluta que representa su libro El Aleph, al que califica de «joya de un americano-español» ${ }^{106}$.

\section{RESOLUCIÓN FINAL DEL POETA}

La demolición que Juan Ramón lleva a cabo de la novela realista, a través de su crítica, no le induce a pronosticar el «agotamiento» o decadencia del género ${ }^{107}$ sino que, por el contrario, le lleva a conectar con las

${ }^{103}$ Cfr. Juan Ramón de viva voz, I, ob. cit., p. 233, nota del 28 de abril de 1931.

En un fragmento de Tiempo, largo poema en prosa escrito por el poeta en 1942 y en el que también recurre al «monólogo interior», Juan Ramón compara su técnica monologuista con la de algunos grandes novelistas europeos de principios del siglo XX. Ésta fue la diferencia observa con aquellos: «Desde muy joven pensé en el luego llamado «monólogo interior» (nombre perfecto como el otro «realismo májico») aunque sin ese nombre todavía; y en toda mi obra hay muestras constantes de ello. (El Diario de un poeta está lleno de esos estados.) Mi diferencia con los «monologuistas interiores» que culminaron en Dujardin, James Joyce, Perse, Eliot, Pound, etc., está en que para mí el monólogo interior es sucesivo, sí, pero lúcido y coherente. Lo único que le falta es argumento. Es como sería un poema de poemas sin enlace lójico. Mi monólogo es la ocurrencia permanente desechada por falta de tiempo y lugar durante todo el día, una conciencia vijilante y separadora al marjen de la voluntad de elección» (Tiempo y Espacio, ed. de Arturo del Villar, Madrid, Edaf, p. 58)

${ }^{104}$ Para el poeta es evidente que éste último se inspiró en la novela de Steinbeck Grapes of Wrath para escribir For whom the Bells Toll (cfr. El Modernismo. Notas de curso, ob. cit., p. 132).

${ }^{105}$ A sus alumnos de la Universidad de Puerto Rico, les recomienda encarecidamente la lectura de este libro en una de las clases. En su aprecio, llega a comparar esta obra con El Quijote: «Don Segundo Sombra - dice el poeta- tiene una idea de $E l$ Quijote. Don Segundo, que no quiere dejar de ser gaucho a pesar de su vejez (...) Este es el mejor libro de Hispanoamérica, recordando al Quijote» (ibídem, p. 135).

${ }^{106}$ Cartas. Antología, ob. cit., p. 181. Ver también Conversaciones con Juan Ramón Jiménez, ob. cit., p. 77.

${ }^{107}$ Sí llegó a esta conclusión uno de sus coetáneos, Ortega y Gasset. A pesar de haber desempeñado un importe papel como rector e instigador de las nuevas tendencias novelísticas, el filósofo madrileño realiza un análisis sombrío del panorama del género: «Los editores - afirma - se quejan de que mengua el mercado de la novela. Acaece, en efecto, que se venden menos novelas que antes y que relativamente aumenta la demanda 
inquietudes de los novelistas renovadores de su tiempo, de cuyas propuestas estéticas - «novela formal»o «lírica», «novela intelectual», etc.- dio sobradas pruebas de ser buen conocedor. Nada más lógico, pues, que el poeta hubiera aprovechado estos aires renovadores para retomar y desarrollar sus numerosísimos proyectos de novelas. Y sin embargo, sus bocetos se quedaron para siempre inconclusos.

La renuncia de Juan Ramón a culminar cualquiera de sus proyectos novelísticos sólo se entiende si se piensa en la situación límite a la que se vio abocado debido a su inquebrantable decisión de escribir novelas desde su condición de poeta. La renovación novelística de principios del siglo $\mathrm{XX}$ surgió como una reacción «antirrealista» $\mathrm{y}$, como tal, permitió «manipular», trastocar y alterar los elementos tradicionales del género. Sin embargo, este mismo proceso lleva implícito un peligro evidente: la renovación de la novela puede convertirse en destrucción del género si se sobrepasan ciertos límites y, a juicio de Ricardo Gullón, el poeta dio muestras claras de necesitar traspasarlos. En su libro La novela lírica ${ }^{108}$, el citado autor se detiene en estudiar la quebradiza frontera que separa la «novela lírica» (novela-renovada) de la «prosa lírica» (no-novela); comparando el caso de Juan Ramón con el de Azorín. Para R. Gullón, las obras del escritor alicantino muestran la voluntad inequívoca del autor por mantenerse dentro del género de la novela ${ }^{109}$. Por el contrario, Platero y yo, uno de los pocos libros de prosa que Juan Ramón terminó y publicó en vida, no constituye una «novela lírica». A juicio de Gullón, el libro carece de la mínima «continuidad» necesaria para poder ser considerado como tal. El poeta, fiel a su propósito de no claudicar de uno solo de sus principios poéticos, se decanta por la «condensación» antes que por la «dilatación novelizante», por el «impacto súbito del poema en prosa» antes que por «sucesión» de «instantes» que «se engarzan y asocian en su propio fluir» ${ }^{110}$.

de libros con contenido ideológico (...) Poco ha reflexionado sobre las condiciones de la obra artística quien no admite que un género literario se agote (...) Es un error representarse la novela - y me refiero sobre todo a la moderna - como un orbe infinito del cual pueden extraerse siempre nuevas formas. Mejor fuera imaginarla como una cantera de vientre enorme, pero finito. Existe en la novela un número definido de temas posibles. Los obreros de la hora prima encontraron con facilidad nuevos bloques, nuevas figuras, nuevos temas. Los obreros de hoy se encuentran, en cambio, con que sólo quedan pequeñas y profundas venas de piedra.

Sobre ese repertorio de posibilidades objetivas que es el género trabaja el talento. Y cuando la cantera se agota, el talento, por grande que sea, no puede hacer nada» («Ideas sobre la novela» (1925) en Obras completas, III, Madrid, Edición Revista de Occidente, 1947, pp. 387-388).

108 Madrid, Cátedra, 1990

109 Tomando como argumento los textos azorinianos, R. Gullón llega a la conclusión de que, a pesar de «su densa concentración poética», en sus obras «mantiene una estructura narrativa, limitada, pero autosuficiente, tan visible como la de la novela lírica» (ibídem, p. 100)

110 Ibidem, p. 101. 
Juan Ramón parece tener conciencia de ello al negarse a calificar de «novela lírica»o «poemática» a Platero y yo, aún cuando el término gozaba de plena actualidad por entonces. Al poeta le pareció más adecuado y exacto denominarlo «Elejía andaluza» ${ }^{111}$.

El caso de Platero y yo junto con el de otros muchos libros de prosa que, aunque inéditos quedaron muy avanzados a la muerte de Juan Ramón, bien le pudieron servir para darse cuenta de que, su condición de poeta, a la que no estaba dispuesto a renunciar en ningún caso, no se avenía con la novela, ni siquiera con la «novela lírica» y «antirrealista». En cambio, encontraba perfecto acomodo en la «prosa lírica»; eso sí, en una «prosa lírica» abierta a las innovaciones estéticas de su tiempo, bien procedieran de la novela, bien procedieran de otros géneros ${ }^{112}$. Por esta razón, el poeta decidió renunciar definitivamente a escribir sus novelas para dedicar todo su tiempo y esfuerzo a sus libros de «prosa lírica». Así pues, cuando en 1953, ya en el final de su vida, el periodista puertorriqueño Juan Bertoli Rangel le formula la siguiente pregunta: «¿Ha ensayado seriamente otros géneros aparte de la poesía?», el poeta no duda en responder:

Bueno, para mí poesía es todo o, mejor dicho, la poesía está en todo; y, es claro, en todos los jéneros literarios. Para mí, vocación es la lírica en verso o en prosa, en sentimiento y pensamiento ${ }^{113}$.

\section{BIBLIOGRAFÍA}

FERRERAS, Juan Ignacio, Teoría y praxis de la novela. La última aventura de don Quijote, París, Ediciones Hispano-Americanas, 1970.

—, La novela en el siglo XX (hasta 1939), Madrid, Taurus, 1990.

${ }^{111}$ Piénsese que en 1916, un año antes de que apareciera la edición completa de Platero y yo con el subtítulo «Elejía andaluza», Ramón Pérez de Ayala había publicado su trilogía, formada por Prometeo, Luz de domingo y La caída de los Limones, con el título de «Novelas poemáticas de la vida española».

Juan Ramón también utilizó la denominación genérica, creada por él mismo, «Elejías andaluzas», para dar título a un «ciclo» de su «prosa lírica» formado por los siguientes libros y proyectos: Josefito Figuraciones, Entes y sombras de mi infancia, Piedras, flores, bestias de Moguer, En mi casita azul, El poeta en Moguer, Por el cristal amarillo (para más información consultar Juan Ramón Jiménez: La prosa de un poeta, ob. cit., p. 72-85).

112 En efecto, en la extensa producción de «prosa lírica» del poeta se pone de manifiesto la extraordinaria capacidad de recepción y asimilación de las nuevas tendencias estéticas que desarrolló el poeta. Además de aparecer el «monólogo interior» en libros como Diario de un poeta reciencasado o Tiempo, Juan Ramón deforma «esperpénticamente» la realidad en Españoles de tres mundos (1942) o se acerca al surrealismo en Viajes y sueños.

113 Esta entrevista se publicó íntegra en La Prensa, el 1 de febrero de 1953. Más tarde, se recogió en La corriente infinita, ob. cit., p. 248. 
Guerrero RuIz, Juan, Juan Ramón de viva voz, I, ed. de Manuel Ruiz Funes-Fernández, Valencia, Pre-Textos, 1998.

GÓMEZ REDONDO, Fernando, «El discurso narrativo» en El lenguaje literario, Madrid, Edaf, 1994.

Gullón, Ricardo, Conversaciones con Juan Ramón Jiménez, Madrid, Taurus, 1958.

- La novela lírica, Madrid, Cátedra, 1990.

JIMÉNEZ, Carmen, «Sobre un proyecto narrativo de Juan Ramón», Culturas (suplemento cultural de Diario 16), 6 de septiembre de 1987, p. III.

JiMÉNEZ, Juan Ramón, El trabajo gustoso, ed. de Francisco Garfias, México, Aguilar, 1961.

-, La corriente infinita, ed. de F. Garfias, Madrid, Aguilar, 1961.

-, Cartas. Antología, ed. de F. Garfias, Madrid, Espasa-Calpe, 1990.

-, Ideolojía (1897-1957) Metamórfosis, IV, ed. de Antonio Sánchez Romeralo, Barcelona, Antrhopos, 1990.

- Historias y cuentos, ed. de Arturo del Villar, Barcelona, Seix Barral, 1994.

-, Ideolojía, II, ed. de Emilio Ríos, Moguer, Ediciones de la Fundación Juan Ramón Jiménez, 1998.

- Cuentos de antología, ed. de Juan Casamayor Vizcaíno, Madrid, Libros Clan, 1999.

-, El Modernismo. Notas de curso, ed. de Jorge Urrutia, Madrid, Visor Libros, 1999.

ORTEGA Y GASSET, José, «Ideas sobre la novela» en Obras completas, III, Madrid, Alianza Editorial, 1983, pp. 387-419.

PAREDES NÚÑEZ, Juan, «Los «cuentos» de Juan Ramón Jiménez», Cuadernos Hispanoamericanos, 376-378 (octubre-diciembre de 1981), pp. 777-784.

PRAT, Ignacio, «La Cabro: una novela inédita de Juan Ramón Jiménez» en Estudios de poesía contemporánea, Madrid, Taurus, 1982, pp. 87-88.

RISCO, Antonio, «La novela de Azorín y el «Nouveau Roman francés», Revista Canadiense de Estudios Hispánicos, 1 (otoño de 1976), pp. 75-98.

VILlANUEVA, Darío, «Fenomenología y pragmática del realismo literario» en Avances en Teoría de la literatura, Universidad de Santiago, 1994, pp. 165-185.

WilcoX, J. C., «Crímenes naturales: Las prosas tardías de Juan Ramón Jiménez» en Actas del Congreso Internacional Juan Ramón Jiménez prosista, ed. de J. Blasco Pascual y T. Gómez Trueba, Moguer, Ediciones de la Fundación Juan Ramón Jiménez, 2000, pp. 261-293. 


\title{
RESUMEN
}

De por qué Juan Ramón Jiménez renunció a ser novelista: el poeta y su teoría novela, por M. Ángeles Sanz Manzano.

Este artículo tiene por objeto explicar las razones de la renuncia de Juan Ramón Jiménez a convertirse en novelista. A pesar de poseer una notable capacidad inventiva y de estar inmerso en la época más propicia para materializarla, Juan Ramón encuentra un obstáculo insalvable para desarrollar su faceta de novelista. Su propósito era escribir novelas desde su condición de poeta. En consecuencia, quería hacer de sus novelas una prolongación de su poesía. El poeta se percató de lo inviable de su empresa cuando comprobó que algunas de sus normas estéticas no se adecuaban al género de la novela, ni siquiera en su manifestación más cercana a la poesía («novela lírica»).

Palabras clave: Juan Ramón Jiménez, novela, novela lírica.

\begin{abstract}
This article has attempts et explain the reason behind the renunciation of the novel by Juan Ramón Jiménez. apart from possessing a notable capacity for invention and deeply involved in this period in expressing his innovative ideas, Juan Ramón came uo against an impossible obstacle in his plans to develop and express his ideas trough the novel. His aim was to write novels in his capacity as a poet. As a result he wished to create novels as prolongation of his poems. The poet realised the futility of his undertaking when he saw that his major aesthetic norms did not coincide with the genre of the novel, not even in the «novela lírica» and Platero y yo which remain his closest prose expression to poetry.
\end{abstract}

Key words: Juan Ramón Jiménez, novel, liric novel. 